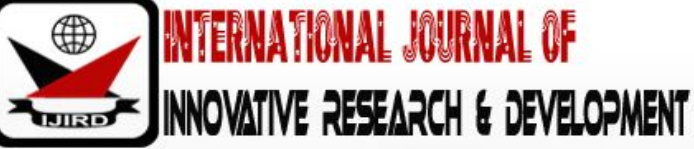

ISSN 2278 - 0211 (Online)

\section{Teacher Pedagogical Competencies for Implementation of Inquiry-Based Science Instruction in Basic Education Classrooms, Taraba State, Nigeria}

\author{
Danjuma Gideon Stella \\ Science Educator, Department of Science Education, Taraba State University, Jalingo, Nigeria
}

\begin{abstract}
:
This study investigated pedagogical competencies present in basic science teachers who used inquiry-based approach for science instruction at the basic education level. The research was carried out in Taraba State of Nigeria. The study adopted a mixed-method model, incorporating the designs of observations and descriptive survey. The sample was made up of 123 basic science teachers. The instruments were an observation protocol of 5 questions and structured questionnaire of 34 items, developed by the researchers. Three research questions and one null hypothesis guided the study. Data analysis was done using researcher observations, mean and standard deviations to answer the research questions; while the t-test was used to test the hypothesis at $p<0.05$ level of significance. Results of the study showed that pedagogical competencies present in the inquiry-based instructional classrooms included 1) teachers' ability to work with students, 2) teachers update their knowledge in science education mostly through in-service training. Teachers' use of inquiry-based approach related to the presenting pedagogical competencies revealed that male and female teachers' instructional classrooms are not significantly different. From the findings, the researchers recommend that basic science teachers should be encouraged to go for regular in-service training in order to become proficient in the required pedagogical competencies for implementation of inquirybased instruction.
\end{abstract}

Keywords: Competency, inquiry - based instruction, basic education

\section{Introduction}

As a field of study concerned with producing a scientifically literate society, science education in Nigeria has been given priority in schools. It is presented to the learner at the basic level of education as Basic science as a core subject which is due to the need for a scientifically and technologically developed nation. This could be achieved through the laying down of a solid foundation for science and technological literacy at the basic level of education as enshrine in the national policy on education (Federal Ministry of Education (FME) (2013). One of the objectives of teaching basic science is to enable the learner to develop interest in science (Nigerian Education Research and Development Council (NERDC)(2007). To achieve this and other objectives, the teacher needs to use the inquiry approach in presenting instruction to the learner (NERDC 2007). However, the use of this approach in Nigeria as a developing nation needs competent teachers for implementing the recommended inquiry-based approach for curriculum delivery.

Competence can be referred to as the ability to perform or complete a given task effectively. It is defined as excellent capability that includes knowledge, skills, attitudes and experiences which has to be target category of profession of the educator (Milan, 2008). Teacher's competencies according to Vickstrom (2008) influence learners. In the same vain, Bhattacharayya, Volk, \& Lumpe (2009); Smolleck, Zembal-Saul, \& Yoder (2006) submitted that teacher's competencies are essential to increase learner's science literacy which consist of meaningful understanding of the subject matter, knowledge of scientific fact and concepts, improvement of their skills and interest in science (Lee, Lewis, Adamson, Maerten - Rivers, \& Secada, 2007). Competence in the teaching profession is made up of four professional roles that teachers have viz: interpersonal, pedagogical, and organizational and the role of an expert in subject matter and teaching methods (Ester, Harm, Hilde, Argen, Ida and Martin, 2012). The authors posited that teachers fulfill these professional roles in relation to four groups of actors in education: working with students, other teachers, the school professional network and himself/ herself. This implies that the teacher that meets these requirements could be considered to be competent. The researcher, based on the submission of Ester, Harm, Hilde, Argen and Martin (2012) and Exline (2004) considered: working with students, other teachers, the school professional network and himself/ herself as criteria for assessing the pedagogical competencies possessed by Basic science teachers for the implementation of Inquiry-based instruction in Taraba State, Nigeria.

Pedagogical competency in teaching could also include the teachers' ability to create a conducive classroom condition that warrants effective interaction in the classroom which is necessary for the implementation of inquiry-based science education. According to Exline (2004) the classroom condition should be such that allows the following: 
- Students view themselves as learners in the process of learning

- Students accept an "invitation to learn" and willingly engage in an exploration process.

- Students raise questions, propose explanations, and use observations.

- Students plan and carry out learning activities.

- Students communicate using a variety of methods.

- Students critique their learning practices

Going by Exlines' submission, there is the need to find out whether the Basic science teacher is capable of creating a classroom condition that can support the use of inquiry approach in delivering instruction because that is what the Nigerian education sector needs for the implementation of the inquiry-based instruction in classrooms.

Inquiry approach according to Omiko (2016) refer to the use of innovative teaching methods such as discovery, problem- solving, open-ended field trips and Laboratory methods among others when disseminating instruction. It is expected that the use of this approach could enable the science teacher to guide learners unto achieving the set objectives of learning basic science thereby attaining the much-needed scientific literacy that may eventually bring about scientific and technological development to the nation. However, Omebe and Omiko (2015) observed that these suggested methods of teaching basic science have been utilized for several years and yet students' result in the Basic Education Certificate Examination (BECE) has not been encouraging. This condition is also experienced in Taraba state north - east, Nigeria where the percentage pass at credit level in the years 2014, 2015 and 2016 has been below 50\% (Taraba State Resource Centre (TSRC), 2017). This could be attributed to the way science instruction is presented to the learner (Kyle, 2006; Onwu \& Kyle, 2011). The authors submitted that Science was presented to the learner from the perspective of normal logical positivism with more emphasis on the mastery of abstract concepts, principles and little connection with day to day life experience of the learner. This status could be attributed to the inappropriate use of inquiry approach by science teachers. It could be in line with this assertion that the federal ministry of education (FME), in collaboration with Japan International Cooperation Agency (JICA), organized an In-Service Education and Training (INSET) program on Strengthening Mathematics and Science Education (SMASE) in Nigeria. The program which has been going on since 2011 till date is aimed at assisting science teachers in developing skills that will enable them use inquiry approach effectively so as to improve achievement in science. (National Teachers Institute (NTI) 2010).

Inquiry- based science instruction (IBSI) is an approach to teaching of science that comes from an understanding of how students learn, the nature of science inquiry, and a focus on the basic concept to be learned (Duchi, Heidi \& Andrew, 2007). The authors reiterated that the approach is based on the belief that it is important to ensure that learners truly understand what they are learning and not simply learn to repeat content and information. They submitted that rather than a superficial learning process in which motivation is based on the satisfaction of being rewarded, IBSI goes deeper and motivation comes from the satisfaction of having learned and understood something. This implies that IBSI is not all about quantities of information memorized, but ideas or concepts leading to understanding that grows deeper and deeper as the learner gets older. This in turn enable the learner to develop intellectual competencies in the form of independent learning, problem - solving, decision making, and critical thinking (National Research Council (NRC) 2011).

To achieve the assertion above, Hently (2006) outlined the following critical areas that need to be looked into: Inquiry based approach, collaborative support, strategies for instruction to improve problem solving and critical thinking strategies for helping students to construct mental models and experience conceptual change, the use of technology and the impact on students and teachers' beliefs. A close look at the Nigerian basic science curriculum shows the inclusion of the various critical areas stated above by Hently, indicating that science teachers are aware of what is expected of them as submitted by Hamza and Nkopodi (2014). The authors opined that the ideas purported by Hently are not new among science teachers, yet the much-desired change anticipated at school level has been low. To effectively connect the teaching of science to day to day experience of the learner, the teacher needs to implement IBSI.

The effective use of inquiry-based instruction at the basic education level could enhance learners' understanding of natural phenomena thereby making science real and part of the learners' life, which happens to be what the twenty first century learning is advocating for (Koay 2013). There also seems to be a consensus among researchers in science education that in order to foster learners' high-level thinking, teachers need to possess not only an in-depth content knowledge, but also a good pedagogical knowledge on how to develop learners' high-order thinking in the content of the subject matter they are handling (Madu 2013, Lederman, Bartos, Berles, Mayer and Schwartz 2014). The Federal Ministry of Education is also aware of this need that is why the Strengthening of Mathematics and Science Education- In-Service Education Training (SMASE-INSET) program has been on for the past six years in Nigeria with the hope of equipping Science and Mathematics teachers with the much-needed skills that will enable them implement IBSI effectively. Apart from assisting the teacher to achieve the set objectives of the curriculum, effective use of inquiry-based instruction also allows learners to explore, explain scientific phenomenon, generate research questions, conduct investigations, generate their own conclusions and communicate with peers in compliance with reform initiatives (National Research Council (NRC) 2012). However, despite all the reform initiatives and limited empirical data documenting the reality of teachers' implementing IBSI in the classroom so far majority of teachers according to Capps \& Crawford (2012) have been found to hold uninformed or naïve conceptions of the nature of science and what constitutes scientific inquiry and its process. One begins to wonder whether these uninformed conceptions has something to do with gender.

Gender is a term used by educationist to make a sociological distinction between male and female members of the society. Aniaku (2012) defined gender as a socio-culturally constructed concept of ascribing some characteristics and roles to sex such as male and female within the society. The concept of gender can be equated to class and race and has many social constructs just as class and race. In Nigeria the issue of gender and gender stereotyping permeate every aspect of human endeavour. Okeke (2007) observed that the circumstances of gender have strongly interacted with culture to 
produce sex role-stereotypes which cut across social, economic, political and educational development especially in the areas of science and technology. Nzewi (2010) explained sex role-stereotypes as the socio-cultural classification of human activities by sex in line with what the society considers as appropriate for one sex or the other. In line with Nzewi's explanation above, the use of inquiry approach in teaching science concepts is one of the human activities carried out in schools which is likely to be influenced by gender. It is in the quest to find out whether this assertion holds true for Basic science teachers in Taraba State that this research was carried out to ascertain the pedagogical competencies of the said teachers in the implementation of IBSI.

The framework of this research, was the social constructivist theory (Vigotsky, 1978). Social constructivist believe that knowledge is subjective and can only be constructed through social interaction and through the ability to identify oneself mentally with what is being constructed and so understand a person, or thing. Regarding the implementation of IBSI in science classrooms, it is important to consider how teachers' understanding of inquiry have developed as a result of the social context in the classroom. For instance, in the process of teaching, learners develop patterns of belief, constructing knowledge in ways they are more familiar with which could be useful to them. Ledederrman (1999) posited that since the construction process is influenced by a variety of social experiences, the knowledge constructed by learners tends not to be completely personal. Ledermans' view shows that the social constructivist perspective is well situated for studying the science teachers' pedagogical competencies in implementing inquiry - based science instruction in basic education classrooms. With regards to this study, the researcher collected and analyzed data with the aim of providing information on the pedagogical competencies of basic science teachers on Implementation of IBSI in Taraba state of Nigeria.

The problem that necessitated this study is the evidence from educational research that revealed Basic Science Examination result to be low over the years in-spite of the use of some innovative teaching methods. The author suspects that the problem may have stemmed from the inability of the teachers to implement the prescribed inquiry-based teaching approach. This study therefore sought to find out the Pedagogical competencies of teachers for the implementation of inquiry - base science instruction in basic education classrooms.

The main purpose of this study was to find out the Pedagogical competencies of teachers for the implementation of inquiry - base science instruction in basic education classrooms in Taraba State, Nigeria and also the influence of gender on the implementation of inquiry- based science instruction

Three research questions guided the study, namely;

- What pedagogical competencies do Basic Science Teachers possess for the implementation of inquiry-based instruction as regards working with students?

- What pedagogical competencies do Basic Science Teachers possess for the implementation of inquiry-based science instruction regarding working with other teachers?

- What pedagogical competencies do Basic Science Teachers possess for the implementation of inquiry-based science instruction with regards to capacity building?

One null hypothesis was formulated at $\mathrm{p}<05$ level of significance, to guide the study, that is: there is no significant gender influence on the pedagogical competencies possessed by male and female basic Science Teachers for the implementation of inquiry-based science instruction in Taraba State.

\section{Method}

The study adopted a mixed -method model, incorporating the designs of observation and descriptive survey. The population of the study consist of five hundred and thirty (530) basic science teachers in Taraba state. The area of study was chosen because of students' poor performance in basic science.

A simple random sampling technique was used to draw a sample of fifty-nine (59) male teachers and sixty-four (64) female teachers making a total of one hundred and forty-nine (123) basic science teachers from the 8 educational zones in the state. The sample was drawn from Government owned secondary schools because the teachers are qualified and hardly go for higher qualification due to funding issues, and others. The instrument for the study were an observation protocol of five (5) questions and a structured questionnaire, containing 34 items developed by the researchers. The questionnaire was made up of 2 sections - section A contains information on respondents' demographic data while section B contains leading questions on teachers' competencies in implementing inquiry- based science education as regards the criteria of working with students, working with other teachers and capacity building. The items for assessing each criterion in section B were formulated on a four-point rating scale of low competence (1- point), medium competence (2points), high competence (3- points) and very high competence (-4 points). The instrument was validated by 2 experts in science education and trial tested on basic science teachers in secondary schools outside the study area. The data collected was analyzed using Cronbach's alpha of internal coefficient and the reliability coefficient was found to be 0.65 . There after copies of the instrument were administered to basic science teachers under study after permission to do so was fully granted by appropriate personnel. The research questions were answered using mean and standard deviation. To arrive at a decision, any item that is positively worded which has a mean score of 2.5 and above is taken as accepted while an item with a mean less than 2.5 is rejected. For the negatively worded items the reverse is the case. The hypothesis was tested by the use of $t$-test analysis at $\mathrm{p}<05$ level of significance. 


\section{Result}

- Research question 1: What pedagogical competencies do Basic Science Teachers possess for the implementation of inquiry-based Science instruction as regards working with students?

\begin{tabular}{|c|c|c|c|c|}
\hline SN & Item Statements & Mean & SD & Remark \\
\hline 1 & Students have access to learning materials & 2.99 & .98 & Accepted \\
\hline 2 & Students work in groups of 4-5 & 2.70 & .92 & Accepted \\
\hline 3 & There is adequate space for students to store finished and \\
unfinished work & 2.43 & .98 & Rejected \\
\hline 4 & I tell students the importance of everyone's ideas & 2.83 & .92 & Accepted \\
\hline 5 & I tell students the value of discussing from many points of view & 3.04 & .91 & Accepted \\
\hline 6 & I ask students leading questions & 2.83 & .93 & Accepted \\
\hline 7 & I ask students thought provoking questions & 2.27 & 1.04 & Rejected \\
\hline 8 & I give students time to think before answering questions & 3.16 & 1.01 & Accepted \\
\hline 9 & 1 allow students talk with seatmate before answering question & 2.26 & .94 & Rejected \\
\hline 10 & I teach students how to disagree respectfully & 2.31 & 1.07 & Rejected \\
\hline 11 & I teach students how to listen to one another & 3.08 & .91 & Accepted \\
\hline 12 & I teach students how to share materials amicably & 2.83 & .95 & Accepted \\
\hline 13 & I teach students how to give everyone time to speak during & 3.27 & .94 & Accepted \\
\hline 14 & group discussion & & & \\
\hline 15 & I tell students objectives of the lesson at the beginning of the & 3.03 & .99 & Accepted \\
\hline 16 & lesson & & & \\
\hline 17 & I use students' prior knowledge and ideas during teaching & 3.07 & .98 & Accepted \\
\hline 18 & I guide students as they design investigations & 3.08 & .91 & Accepted \\
\hline 19 & I guide students to analyze their results to reach valid & 3.08 & .92 & Accepted \\
\hline 20 & Students to record their findings & 3.03 & .88 & Accepted \\
\hline 21 & I assess students' activities at every step of lesson presentation & 3.22 & .89 & Accepted \\
\hline
\end{tabular}

Table 1: Mean and Standard Deviation scores of Respondents Opinion on working with students

From table 1, it could be observed that items, 1,2,4,5,6,8,11,12,13,14,15,16,17,18,19 20, and 21 positively worded with mean $2.99,2.70,2.84,3.05,2.90,2.85,3.16,3.08,2.83,3.27,3.04,3.07,3.09,3.08,3.03,3.16,2.66$ and 3.22 respectively were above the cut-off point (2.5) and were accepted. Items 3, 7, 9 and 10 with means scores of $2.43,2.28,2.25$, and 2.23 respectively were rejected. The response of basic science teachers in Taraba State showed that most of them worked with their students during the teaching process.

- Research question 2: What pedagogical competencies do Basic Science Teachers possess for the implementation of inquiry-based science instruction regarding working with other teachers?

\begin{tabular}{|c|c|c|c|c|}
\hline SN & Item Statements & Mean & SD & Remark \\
\hline 1 & I participate in team teaching & 3.17 & .98 & Accepted \\
\hline 2 & Other teachers help me to create storage space in my classroom & 2.52 & 1.03 & Accepted \\
\hline 3 & $\begin{array}{c}\text { Unavailable teaching materials are borrowed from other } \\
\text { teachers }\end{array}$ & 2.70 & 1.05 & Accepted \\
\hline 4 & I work with other teachers to improvise teaching materials & 2.96 & .95 & Accepted \\
\hline 5 & $\begin{array}{c}\text { I share ideas with other teachers on concepts I find difficult to } \\
\text { teach }\end{array}$ & 2.99 & 1.08 & Accepted \\
\hline 6 & $\begin{array}{c}\text { Other teacher uses my lesson plan to stand in for me when the } \\
\text { need arises }\end{array}$ & 2.93 & 1.06 & Accepted \\
\hline 7 & I use to stand in for other teachers & 2.80 & 1.00 & Accepted \\
\hline
\end{tabular}

Table 2: Mean and Standard Deviation Scores of Respondents' Opinion on Working with Other Teachers

In table 2 above, items 1,2,3,4,5, and 6 with mean scores of .17,2.52,2.70,2.96,2.99,2.93and 2.90 respectively were above the cut-off points and were accepted. This implied that respondents work with other teachers to deliver instruction to students in the study area.

- Research question 3: What pedagogical competencies do Basic Science Teachers possess for the implementation of inquiry-based science instruction as regards capacity building? 


\begin{tabular}{|c|c|c|c|c|}
\hline SN & Item Statements & Mean & SD & Remark \\
\hline 1 & I acquired a higher qualification within the service period & 3.11 & .93 & Accepted \\
\hline 2 & I attend science workshops once a year & 3.00 & .92 & Accepted \\
\hline 3 & I attend seminar every other year & 2.90 & .85 & Accepted \\
\hline 4 & I attend science conference once a year & 2.98 & .93 & Accepted \\
\hline 5 & I attend in-service training on regular basis & 3.62 & .88 & Accepted \\
\hline 6 & $\begin{array}{c}\text { I put into practice what I learned during in-service training into } \\
\text { practice }\end{array}$ & 3.18 & 1.00 & Accepted \\
\hline
\end{tabular}

Table 3: Mean and Standard Deviation Scores of Respondents' Opinion on Capacity Building

Items $1,2,3,4,5$, and 6 on table 3 with the mean values of $3.11,3.00,2.90,2.98,3.62$ and 3.18 were accepted since the values were found to be above the cut-off points of 2.5 mean score. The table revealed that all the respondents use to update their skills from time to time.

- Hypothesis $\left(\mathrm{H}_{01}\right)$ : There is no significant gender influence in the pedagogical competencies possessed by male and female basic Science Teachers in the implementation of inquiry-based science instruction for all the categories.

\begin{tabular}{|c|c|c|c|c|c|c|c|}
\hline Variable & Gender & $\mathbf{N}$ & Mean & SD & DF & T & P-Value \\
\hline Working with students & Male & 59 & 3.00 & 0.48 & .121 & 1.1794 & 0.07 \\
\hline & Female & 64 & 2.79 & 0.75 & & & \\
\hline Working with other teachers & Male & 59 & 3.02 & 0.63 & 121 & 1.874 & 0.07 \\
\hline & female & 64 & 2.77 & 0.86 & & & \\
\hline Capacity building & Male & 59 & 2.93 & 0.61 & 121 & 1.59 & 0.11 \\
\hline & female & 64 & 3.10 & 0.62 & & & \\
\hline
\end{tabular}

Table 4: T-Test Analysis on the Influence of Gender in the Competencies Possessed by Basic Science Teachers

Data in Table 4 showed that the associated probability values of $0.07,0.07$ and 0.11 are greater than 0.05 set as level of significance. This is an indication that Gender does not have significant influence in the pedagogical competencies possessed by Basic Science teachers for the implementation of inquiry-based science instruction in Taraba State.

\begin{tabular}{|c|c|c|}
\hline Item Statements & Observation & Remark \\
\hline Interaction between teacher and students & $\begin{array}{l}\text { Teacher } \\
\text { interacts with } \\
\text { students }\end{array}$ & $\begin{array}{c}\text { Needs } \\
\text { improvement }\end{array}$ \\
Adequate space for storage of finished and & $\begin{array}{l}\text { Inadequate } \\
\text { unfinished work } \\
\text { storage for }\end{array}$ & \\
Teachers' questioning techniques & $\begin{array}{l}\text { Teacher's poor } \\
\text { questioning } \\
\text { techniques }\end{array}$ & \\
\hline Teacher working with other teachers & $\begin{array}{l}\text { Teacher work with } \\
\text { other teachers }\end{array}$ & good \\
\hline Students working with students & $\begin{array}{l}\text { Students don't } \\
\text { accept criticism } \\
\text { in good faith } \\
\text { Students } \\
\text { collaborate }\end{array}$ & Needs \\
& improvement \\
& Good \\
\hline
\end{tabular}

Table 5: Observation Protocol

Table 5 revealed the outcome of the researchers' observations on the teachers' ability to work with students, other teachers and students' ability to work with one another in the Basic science classroom. It was observed that Basic science teachers work with other teachers and with students but they exhibit poor questioning techniques. The table also showed that student work with one another but they find it difficult to accept criticism on their work from one another.

\section{Discussion}

The results of the study revealed that most of the respondents accepted that they work with their students during the process of teaching and learning. For them to be able to work with students they must have created a conducive classroom condition which enhances interaction between the teacher and the students. The teacher that is able to work with students could equally influence them towards learning and doing science. This skill is one of the skills exhibited by a competent teacher as submitted by Vickstrom (2008) who stated that teachers' competencies influence learners. The teacher could also assist the learners in developing science process skills which will lead to their acquiring scientific attitudes, thereby increasing their level of scientific literacy. In the same vain, Bhattacharayya, Volk, \& Lumpe (2009); 
Smolleck, Zembal-Saul, \& Yoder (2006) submitted that teachers' competencies are essential to increase learner's science literacy which consist of meaningful understanding of the subject matter, knowledge of scientific fact and concepts, improvement of their skills and interest in science. Competence in the teaching profession according to Ester, Harm, Hilde, Argen, Ida and Martin (2012) is made up of four professional roles that teachers have viz: interpersonal, pedagogical, and organizational and the role of an expert in subject matter and teaching methods The authors posited that teachers fulfill these professional roles in relation to four groups of actors in education: working with students, other teachers, the school professional network and himself/herself. This implies that the teacher that meets these requirements could be considered to be competent. Therefore, since the result of this study revealed that the subjects of this study work with students and other teachers when delivering basic science instruction, it implies that they are competent for implementing inquiry - based science instruction.

The results of the study also showed that the respondents update their knowledge in Science education by getting additional qualification, attending seminar and conference as well as in-service training. This capacity building exercises undertaken by basic science teachers in Taraba State could account for their ability to work with students and other teachers indicating their ability to play the four professional roles expected of teachers. The roles are: interpersonal, pedagogical, and organizational and the role of an expert in subject matter and teaching methods (Ester, Harm, Hilde, Argen, Ida and Martin, 2012). Therefore, going by the submission of these authors basic science teachers in Taraba State are competent on the implementation of inquiry-based science education.

The t-test analysis on influence of gender on the competencies of Basic Science teacher in the implementation of inquiry-based science education in Taraba state showed that the p-value in all the criteria used for the study ( i.e. working with students, working with other teachers and capacity building) were above the set 0.05 level of significance Therefore the null hypothesis was upheld , meaning that the influence of gender on Taraba State Basic Science teachers' competencies for the implementation of inquiry-based Science education is not significant.

Based on the findings of the research it was recommended that:

- Investigation should be carried out to ascertain the level of competencies for implementation of inquiry-based science instruction possessed by basic science teachers in other states of Nigeria

- Non-Governmental organizations should provide opportunities for basic science teachers to attend regular inservice training programs so as to become proficient in the required pedagogical competencies for the implementation of inquiry-based science instruction enable them improve their skills

- Regular supervision of Basic Science teachers to ensure their effective use of inquiry approach by Monitoring and Evaluation officers from the Ministry of Education

\section{References}

i. Aniaku, O. L. (2012). Effects of Guided and Unguided Inquiry Teaching Methods on Secondary School Students' Achievement and Interest in Biology in Enugu State www.unn.edu.ng

ii. Taraba State Educational Resource Center (TSRC) (2017). Basic Education Certificate Examination (BECE), (2014; 2015 \& 2016).

iii. Bhattacharayya, S., Volk, T., \& Lumpe, A. (2009). The Influence of an Extensive Inquiry-Based Field Experience on Pre-Service Elementary Student Teachers' Science Teaching Beliefs. Journal of Science Teacher Education, 20(1), 199 - 218.

iv. Capps, k., Crowford, B. A. (2012). Inquiry Based Instruction and Teaching about Nature of Science. Are they happening? Journal of Science Teacher Education. Springer.

v. Dusch, R., Heidi, S. \& Andrew S. (2007). Taking Science to School: Learning \& Teaching Science in Grade k-8. Washington DC. The National Academies Press

vi. Ester A.T; Harm J.A.B.; Argen, E.J.W, Ida, O. \&Martin, M. (2012). Inquiry-Based Science Education. Competencies of Primary School Teachers: A Literature Study and Critical Review of American National Science Education Standards. International Journal of Science Education 34 (17). Pp. 2609-2640.

vii. Exline Joe(2004).Inquiry-Based Learning. Classroom.www.thirteen.org/ edonline/ concept2class/ inquiry/ indexsub2.html

viii. Federal Republic of Nigeria (FRN, 2013). National Policy on Education (4th Edition). NERDC.

ix. Hamza, O. Mand Nkopodi, N. (2014). Inquiry - Based Teaching in Physical Science: Teachers' Instructional Practices and Conceptions. Mediterranean Journal of Social Sciences 5(23), MCSER Publishing, Rome, Italy 10741082.

x. Koay Suan See (2013). 21stCentury Learning. Handout for Third Country Training Program, SEAMEO RECSAM, Penang, Malaysia.

xi. Lee, O., Lewis, S., Adamson, K., Maerten-Rivera, J., \&Secada, W.G. (2007). Urban Elementary School Teachers' Knowledge and Practices in Teaching Science to English Language Learners. Science Education, 92, 733 - 75

xii. Lederman, J.S.; Lederman, N. G.; Banjos, S.A.; Barles, S. L.;Mayer, A. A. (2014). Meaningful Assessment of Learners' understanding about Scientific Inquiry. The Views about Scientific Inquiry (VASI) Questionnaire. Journal of Research in Science Teaching 51(1) 65-83.

xiii. Madu, A. V. (2013). Teaching Difficulties from Interaction in Discourse in a Science Classroom. Journal of Science Education \& Social Research 3(3), 113.

xiv. Milan Slavick (2008). Teacher's Competencies https:/ / www.slideshave.net

xv. Mulder, M. (2001). Competentont wikkeling in Organisaties. Perspectieven en Praktijk. [Competence Development in Organisations. Perspectives and Practises]. 'S-Gravenhage: Elsevier Bedrijfsinformatie. 
xvi. National Research Council, (2011). A Framework for k-12 Science Education: Practices,

Crosscutting

Concepts, and Core ideas. . Washington dc: The National Press.

xvii. National Research Council, (2012). A Framew ork for k-12 Science Education: Practices, Concepts, and Core Ideas. Washington DC: The National Academies Press.

xviii. NERDC (2007). Basic Science Curriculum Federal Ministry of Education Nigeria.

xix. Nzewi, U.M. (2010) Thermal Pollution. In Uchenna Nzewi \& Ben Uzoechi (Eds) Strategies for Environmental Education: Focus on Noise, Thermal and Radioactive Pollution. Ibadan: Science Teachers' Association of Nigeria, (STAN) EE Series no 14: 18-26.

xx. Okeke, E. A. C. (2007). Sex Difference in the Understanding of some Important Biology Concepts. Nigeria Journal of education, 2(1), 125-132.

xxi. Omebe, C. A. and Omiko, A. (2015). Effects of Instructional Resources on Students' Achievement in Secondary Schools in Ebonyi State, Nigeria. Journal of the Science Teachers' Association of Nigeria (JSTAN). 50(1)174-183.

xxii. Omiko Akani (2016). An Evaluation of Classroom Experience of Basic Science Teachers in Secondary Schools in Ebonyi State of Nigeria. British Journal of Education 4(11)64-76.

xxiii. SMASE- INSET Nigeria, (2010). Handout Notes on Strengthening Mathematics and Science Education and InService Education and Training in Nigeria. FME/ NTI/JICA.

xxiv. Smolleck, L.D., Zembal-Saul, C., \& Yoder, E.P. (2006). The Development and Validation of an Instrument to Measure Pre-Service Teachers' Self-Efficacy In Regard to the Teaching of Science as Inquiry. Journal of Science Teacher Education, 17, 137- 163.

xxv. Schraw, G., Crippen, K. J, \& Hartley, K. (2006). Promoting Self-Regulation in Science: Metacognition as Part of a Broader Perspective on Learning. Journal of Research in Science Education, 36(1-2), 111-139.

xxvi. Schwartz, R. \& Lederman, N. (2008). What Scientist say: Scientist view of Nature of Science in Relation to Science Context. International Journal of Science Education, 30 (6), 727- 771.

xxvii. TSRC (2017). Record of BECE Result. Jalingo, Taraba state Vigotsky (1978). Mind in Society, London. Harvard University.

xxviii. Vikstrom, A. (2008). What is Intended, what is Realized, and What is Learned? Teaching and Learning Biology in the Primary School Classroom. Journal of Science Teacher Education, 19, 211 - 233. 